\title{
Morpho-physiological response of Solanum macrocarpon $L$. seedlings to different light intensities
}

\section{Damilola Grace Ogunrotimi and Joshua Kayode}

Department of Plant Science and Biotechnology. Faculty of Science. Ekiti State University. Ado Ekiti. Nigeria.

\begin{abstract}
Seedlings of Solanum macrocarpon L. were transplanted into experimental pots containing $3 \mathrm{~kg}$ soil and placed under different levels of solar radiation to investigate their response to light intensities. The growth parameters revealed that seedlings under direct sunlight performed better than the ones under shade of mesh net. The plants growing under the shade had stunted growth and were highly susceptible to leaf abscission compared to those under direct sunlight which produced healthy stem and sturdy leaves. This could suggest S. macrocarpon possess higher tolerance to solar radiation. However, seedlings of under direct sunlight produced higher leaf area, leaf number, plant height and stem diameter than those under shade. High leaf area is important for light interception to allow for photosynthesis. These findings revealed that Solanum macrocarpon grows optimally under direct sunlight.
\end{abstract}

Keywords: Solanum macrocarpon; Growth; Light; Plant; Seedlings.

\section{Introduction}

Light is an abiotic factor that is necessary for plant growth and development. It largely influences photosynthetic rate and also plays substrate and regulatory roles (Sysoeva et al., 2010). Growth of plants in the natural environment is subject to varying light conditions depending on whether they are growing in open field or under
Received

April 23, 2018

Accepted

August 19, 2018

Released

August 31, 2018

Full Text Article

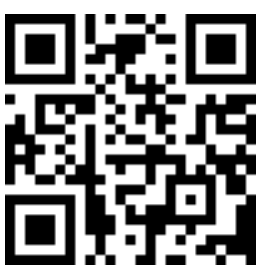

ORCID

(D) 0000-0002-2999-928X

Damilola Grace

Ogunrotimi

D 0000-0002-7467-5276

Joshua Kayode 
transpiration rate thereby reducing water available for plant metabolism.

During photosynthesis, solar energy reacts with carbon (IV) oxide and water to produce the sugar that drives plant cellular processes giving oxygen as a by-product. It is important to note that photosynthesis decline is expected in plants growing in shady environment, however Hoddinott and Hall (1982) described the 'Emerson enhancement effect' which serves to increase the overall rate of photosynthesis under shade conditions. Crop yield is photosynthetically dependent. Sunlight fosters active transport of solutes across membranes and stimulates uptake of sugar by plant tissues. It is important to note that high leaf temperature inactivate the plant enzyme system, changes sugars to starch, resulting in sugar accumulation and lower photosynthesis (Bamigboye and Kayode, 2016).

Solanum macrocarpon L., popularly known as African eggplant is an indigenous vegetable which is highly underutilized. It is an erect, herbaceous perennial herb and grows up to about 1$1.5 \mathrm{~m}$ tall. It is thought to be a native of Africa although it is now widely distributed in different ecological zones. It is naturally found growing in the wild and sometimes in residential areas but not properly domesticated even though it can be cultivated at low cost in home gardens. Solanum macrocarpon in its cooked form can serve as natural antioxidant and supplement to diets. Indigenous vegetables contain phenolic antioxidants and ascorbic acid, among others, which help to slow down the process of degenerative diseases (Odukoya et al., 2007).

Recently, studies have been focused on the effect of some abiotic stress factors such as water deficit, salt and soil concentrations, fertilizer application on plant growth, productivity and secondary metabolites composition (Bettaieb et al., 2009; Corell et al., 2009,
Ayeni et al., 2013, Bvenura and Afolayan, 2014).

The objective of this study is therefore to investigate the effect of light on the morphology and physiology of $S$. macrocarpon so as to establish the optimum intensity under which it will thrive successfully.

\section{Materials and methods}

\section{Germination experiment}

Sand was collected at the Parks and Gardens Unit of Ekiti State University, Ado-Ekiti, Nigeria. Plastic trays of about $40 \mathrm{~cm}$ in diameter were filled with sand and Solanum macrocarpon seeds sown under green house conditions. Seeds were watered daily and germination of seeds was observed five days after sowing.

\section{Growth experiment}

Experimental pots with perforations at the base to allow for water drainage were filled with $3 \mathrm{~kg}$ sand. Uniformly growing seedlings with up to two leaves stage were transplanted from plastic trays into the experimental pots already filled with topsoil. Three pots were allocated according to different light intensities and then replicated three times. Wooden frames used for the experiment were made with wood of $6 \times 4 \mathrm{~cm}$ in thickness. The dimension of each frame is $90 \times 90 \times 100$ $\mathrm{cm}$. The wooden frames were then covered on all sides with single and double layers of synthetic green $1 \mathrm{~mm}$ mesh net bought from local market to achieve $75 \%$ and $50 \%$ light intensities respectively. The one layer of mesh net reduced light by $25 \%$ and the other with double layer mesh net reduced light by $50 \%$ light intensities respectively; while seedlings grown in the open nursery received $100 \%$ light.

The seedlings were exposed to the three different light intensities $(100 \%, 75 \%$ and $50 \%)$ as described above. Thus, the seedling growth was 
monitored under three different light intensities as follows:

- The first group was placed under the double layer mesh net (50\%) receiving average light intensity of 12,200 lux.

- The second group received average light intensity of 13000 lux and was placed under the single layer mesh net (75\%).

- The third group (control) was made to receive direct sunlight $(100 \%)$ emitting an average of 23,500 lux of light by placing them in the open space beside the Department of Plant Science and Biotechnology Laboratory, Ekiti State University, Ado-Ekiti, Nigeria.

\section{Light measurement}

A digital lux meter was used to measure solar radiation in full sunlight and under the shades of wooden frame. The seedlings were watered daily throughout the duration of the experiment.

\section{Measurement of growth parameters}

Data were collected for early seedling growth parameters such as plant height, stem diameter, leaf number, leaf length and leaf breadth. Plant height, leaf length and breadth were measured using a meter rule, stem diameter measured with the aid of a digital Vernier caliper while leaf number was obtained by physical counting. Leaf area was determined using the non destructive method (Saxena and Singh, 1965) and computed using the formula:

\section{Leaf area $=0.75$ (Leaf Length $\times$ Leaf Breadth)}

Where 0.75 is the correction factor for the leaf shape.

\section{Statistical analysis}

Data obtained from various treatments were subjected to statistical analysis using SPSS 20. A one way analysis of variance was used to compare the means of each treatment. Means were segregated using Duncan's Multiple Range Test. The means were treated as significantly different at $\mathrm{p}<0.05$.

\section{Results}

The effect of light intensities on growth parameters are presented in
Tables 1 to 4 . The highest mean leaf area was obtained in seedlings under direct sunlight $\left(55.91 \mathrm{~cm}^{2}\right)$ at 9 WAT and lowest in single-layered mesh net $\left(3.20 \mathrm{~cm}^{2}\right)$ at 3 WAT (Table 1). The result showed that significant differences existed between the three levels of light intensities except at 7 WAT and 8WAT. Mean plant height was highest in seedlings placed under direct sunlight at 9 WAT $(8.00 \mathrm{~cm})$ and lowest in doublelayered net $(3.40 \mathrm{~cm})$ at 3 WAT (Table 2$)$. 
Table 1. Effect of light intensity on leaf area $\left(\mathrm{cm}^{2}\right)$ of Solanum macrocarpon.

\begin{tabular}{lccccccc}
\hline & \multicolumn{7}{c}{ Plant age WAT } \\
\cline { 2 - 8 } & $\mathbf{3}$ & $\mathbf{4}$ & $\mathbf{5}$ & $\mathbf{6}$ & $\mathbf{7}$ & $\mathbf{8}$ & $\mathbf{9}$ \\
\hline Double-layered net & $3.20 \pm$ & $3.35 \pm$ & $3.46 \pm$ & $3.96 \pm$ & $4.57 \pm$ & $5.47 \pm$ & $5.89 \pm$ \\
& $0.29^{\mathrm{a}}$ & $0.14^{\mathrm{a}}$ & $0.28^{\mathrm{a}}$ & $0.18^{\mathrm{a}}$ & $0.31^{\mathrm{a}}$ & $0.23^{\mathrm{a}}$ & $0.24^{\mathrm{a}}$ \\
Single-layered net & $3.49 \pm$ & $4.25 \pm$ & $6.10 \pm$ & $6.21 \pm$ & $8.05 \pm$ & $9.75 \pm$ & $11.64 \pm$ \\
& $0.03^{\mathrm{a}}$ & $0.35^{\mathrm{a}}$ & $1.04^{\mathrm{a}}$ & $0.77^{\mathrm{a}}$ & $1.03^{\mathrm{a}}$ & $1.27^{\mathrm{ab}}$ & $1.81^{\mathrm{ab}}$ \\
Direct Sunlight & $10.43 \pm$ & $16.38 \pm$ & $20.56 \pm$ & $38.00 \pm$ & $45.51 \pm$ & $53.11 \pm$ & $55.91 \pm$ \\
(Control) & $0.41^{\mathrm{b}}$ & $3.00^{\mathrm{b}}$ & $4.88^{\mathrm{b}}$ & $17.00^{\mathrm{a}}$ & $20.07^{\mathrm{a}}$ & $22.09^{\mathrm{b}}$ & $22.17^{\mathrm{b}}$ \\
\hline
\end{tabular}

* WAT: Weeks after transplanting.

Values shown are mean \pm S.E.

Means with different letters down the same column represent significant differences at $\mathrm{p}<0.05$.

Table 2. Effect of light intensity on plant height $(\mathrm{cm})$ of Solanum macrocarpon.

\begin{tabular}{lccccccc}
\hline & \multicolumn{7}{c}{ Plant age WAT } \\
\cline { 2 - 8 } & $\mathbf{3}$ & $\mathbf{4}$ & $\mathbf{5}$ & $\mathbf{6}$ & $\mathbf{7}$ & $\mathbf{8}$ & $\mathbf{9}$ \\
\hline Double-layered net & $3.40 \pm$ & $2.83 \pm$ & $3.23 \pm$ & $3.23 \pm$ & $3.73 \pm$ & $3.80 \pm$ & $4.13 \pm$ \\
& $0.30^{\mathrm{a}}$ & $0.60^{\mathrm{a}}$ & $0.60^{\mathrm{a}}$ & $0.64^{\mathrm{a}}$ & $0.41^{\mathrm{a}}$ & $0.44^{\mathrm{a}}$ & $0.35^{\mathrm{a}}$ \\
Single-layered net & $5.10 \pm$ & $5.27 \pm$ & $4.17^{\mathrm{a}} \pm$ & $4.43 \pm$ & $5.00 \pm$ & $5.23 \pm$ & $5.57 \pm$ \\
& $0.97^{\mathrm{ab}}$ & $1.77^{\mathrm{a}}$ & $0.69^{\mathrm{a}}$ & $0.64^{\mathrm{ab}}$ & $0.64^{\mathrm{ab}}$ & $0.55^{\mathrm{b}}$ & $0.64^{\mathrm{a}}$ \\
Direct Sunlight & $7.57 \pm$ & $4.83 \pm$ & $5.17 \pm$ & $5.47 \pm$ & $6.40 \pm$ & $6.87 \pm$ & $8.00 \pm$ \\
(Control) & $0.63^{\mathrm{b}}$ & $0.73^{\mathrm{a}}$ & $0.64^{\mathrm{a}}$ & $0.44^{\mathrm{b}}$ & $0.06^{\mathrm{b}}$ & $0.13^{\mathrm{c}}$ & $0.66^{\mathrm{b}}$ \\
\hline
\end{tabular}

* WAT: Weeks after transplanting.

Values shown are mean \pm S.E.

Means with different letters down the same column represent significant differences at $\mathrm{p}<0.05$.

The result showed significant difference in mean plant height all through the experimental period. The stem diameter increased consistently throughout the experiment except for fluctuations observed in double-layered net (Table 3). Seedlings in direct sunlight (control) produced sturdy stems and appeared very healthy compared to those under shade. The highest stem diameter $(2.38 \mathrm{~mm})$ at 9 WAT was produced by seedlings under direct sunlight while the lowest was obtained in double-layered net $(0.63 \mathrm{~mm})$. Stem diameter was significantly affected by light intensity. The highest leaf number was recorded in seedlings in the control experiment (12.00) while the lowest number of leaves was obtained in seedlings placed under double-layered mesh net (2.67). Seedlings growing under the mesh nets experienced constant leaf abscission which led to reduction in leaf number especially from 7 WAT to the end of the experiment. Differences in mean leaf number were significant from 4 WAT to 9 WAT. 
Table 3. Effect of light intensity on stem diameter (mm) of Solanum macrocarpon.

\begin{tabular}{lccccccc}
\hline & \multicolumn{7}{c}{ Plant age WAT } \\
\cline { 2 - 7 } & $\mathbf{3}$ & $\mathbf{4}$ & $\mathbf{5}$ & $\mathbf{6}$ & $\mathbf{7}$ & $\mathbf{8}$ & $\mathbf{9}$ \\
\hline Double-layered net & $0.63 \pm$ & $0.70 \pm$ & $0.87 \pm$ & $0.82 \pm$ & $0.83 \pm$ & $0.85 \pm$ & $0.94 \pm$ \\
& $0.04^{\mathrm{a}}$ & $0.03^{\mathrm{a}}$ & $0.06^{\mathrm{a}}$ & $0.07^{\mathrm{a}}$ & $0.06^{\mathrm{a}}$ & $0.07^{\mathrm{a}}$ & $0.07^{\mathrm{a}}$ \\
Single-layered net & $0.80 \pm$ & $0.98 \pm$ & $0.91 \pm$ & $0.86 \pm$ & $0.87 \pm$ & $1.21 \pm$ & $1.24 \pm$ \\
& $0.00^{\mathrm{b}}$ & $0.14^{\mathrm{a}}$ & $0.05^{\mathrm{a}}$ & $0.03^{\mathrm{a}}$ & $0.03^{\mathrm{a}}$ & $0.30^{\mathrm{a}}$ & $0.30^{\mathrm{a}}$ \\
Direct Sunlight & $1.61 \pm$ & $1.73 \pm$ & $1.76 \pm$ & $2.18 \pm$ & $2.20 \pm$ & $2.35 \pm$ & $2.38 \pm$ \\
(Control) & $0.07^{\mathrm{c}}$ & $0.03^{\mathrm{b}}$ & $0.16^{\mathrm{b}}$ & $0.31^{\mathrm{b}}$ & $0.31^{\mathrm{b}}$ & $0.35^{\mathrm{b}}$ & $0.33^{\mathrm{b}}$ \\
\hline
\end{tabular}

* WAT: Weeks after transplanting.

Values shown are mean \pm S.E.

Means with different letters down the same column represent significant differences at $\mathrm{p}<0.05$.

Table 4. Effect of light intensity on leaf number of Solanum macrocarpon.

\begin{tabular}{lccccccc}
\hline & \multicolumn{7}{c}{ Plant age WAT } \\
\cline { 2 - 7 } & $\mathbf{3}$ & $\mathbf{4}$ & $\mathbf{5}$ & $\mathbf{6}$ & $\mathbf{7}$ & $\mathbf{8}$ & $\mathbf{9}$ \\
\hline Double-layered net & $3.67 \pm$ & $3.00 \pm$ & $3.33 \pm$ & $2.67 \pm$ & $3.33 \pm$ & $3.00 \pm$ & $3.00 \pm$ \\
& $0.33^{\mathrm{a}}$ & $0.00^{\mathrm{a}}$ & $0.33^{\mathrm{a}}$ & $0.67^{\mathrm{a}}$ & $0.33^{\mathrm{a}}$ & $0.00^{\mathrm{a}}$ & $0.00^{\mathrm{a}}$ \\
Single-layered net & $3.67^{ \pm}$ & $3.67^{\mathrm{a}}$ & $4.67^{\mathrm{a}}$ & $4.33 \pm$ & $4.33 \pm$ & $4.00 \pm$ & $4.33 \pm$ \\
& $0.33^{\mathrm{a}}$ & $0.33^{\mathrm{a}}$ & $0.33^{\mathrm{a}}$ & $0.33^{\mathrm{a}}$ & $0.33^{\mathrm{a}}$ & $0.33^{\mathrm{a}}$ & $0.33^{\mathrm{a}}$ \\
Direct Sunlight & $4.33^{\mathrm{a}}$ & $4.67 \pm$ & $5.00 \pm$ & $5.33 \pm$ & $9.00 \pm$ & $9.67 \pm$ & $12.00 \pm$ \\
(Control) & $0.33^{\mathrm{b}}$ & $0.33^{\mathrm{b}}$ & $0.58^{\mathrm{b}}$ & $0.67^{\mathrm{b}}$ & $1.53^{\mathrm{b}}$ & $1.20^{\mathrm{b}}$ & $1.53^{\mathrm{b}}$ \\
\hline
\end{tabular}

* WAT: Weeks after transplanting.

Values shown are mean \pm S.E.

Means with different letters down the same column represent significant differences at $\mathrm{p}<0.05$.

\section{Discussion}

Light is an essential environmental factor which supports chlorophyll production. In the present study, the amount of light intensity received by Solanum macrocarpon seedlings significantly affected its physiology and morphology. The seedlings under direct sunlight received $100 \%$ light intensity, the single-layered net produced $25 \%$ light interception thereby making $75 \%$ light available to the seedlings under it. Also, the doublelayered net reduced light by $50 \%$ providing $50 \%$ light to the seedlings. Several authors have opined that the amount of light a plant receives determines it growth and development, some plants even have the ability to germinate under dark conditions (Bewley and Black, 1994; Ochuodho and
Modi, 2005; Sowunmi and Afolayan, 2015).

The present study showed that $S$. macrocarpon does not readily adapt to shade conditions. Seedlings under double and single layered mesh nets performed poorly when compared to those under direct sunlight. This supports the findings of Aderounmu (2010) who observed that optimum light intensity is necessary for healthy seedling development. The high leaf area observed in the seedlings under direct sunlight may help to support chlorophyll production as this will provide a large surface area for light impingement. Hangarter (1997) stated that the quality, quantity and direction of light as perceived by a plant's photosensory help to regulate plant development and maintain photosynthetic efficiency. In their study of the effect of light stress on 
germination and growth parameters of Corchorus olitorius, Celosia argentea, Amaranthus cruentus, Abelmoschus esculentus and Delonix regia, Ologundudu et al. (2013) concluded that fluctuations in light intensity lead to stress thereby altering a plant's morphology. This current study also observed that stem diameter and leaf production continually declined at a stage in seedlings growing under the mesh nets, this tend to suggest that this plant's survival depends on efficiency with which they capture and utilize light. According to Kephart and Taylor (1992), increased stem elongation occurs with moderate reductions in irradiance and influenced by photosynthetate availability and partitioning leading to stem growth. This agrees with the result of this study as seedlings under shade show reduced height and thin stems. However, it is important to note that high light intensity for an extensive period may lead to scorching of leaves. Some authors have stated that longer exposure to higher light intensities could damage a plant's photosynthetic apparatus leading to partial loss of its photosynthetic function as earlier suggested for Paeonia suffruticosa and Salvia officinalis (Zhang et al., 2003; Zervoudakis et al., 2012).

$$
\text { Devkota and Hogson (2000) }
$$$$
\text { stated that plant morphological }
$$
adaptation to low light intensity lead to the production of long and narrow leaves that possess higher specific leaf area to support light interception. The results from the study showed that the plants growing under shade could not adapt to low light intensity and as a result produced low leaf area. However, the large surface area of plants growing under direct sunlight promoted stomatal conductance. In this study, other necessary environmental factors such as moisture and air needed for proper growth and development were adequate except for variation in light intensity which resulted in stunted growth of plants place under shade.

\section{Conclusion}

The study shows that Solanum macrocarpon is not a shade tolerant species as the growth parameters studied were significantly affected by the low light intensity. Vegetable production is ultimately determined by appropriate physiological and morphological conditions of which light is a very important factor. It is therefore advised that propagation of $S$. macrocarpon must be carried out under appropriate light condition to support its optimum growth and development.

\section{Conflict of interest}

The authors have declared that there is no conflict of interest.

\section{References}

\section{Aderounmu, A. F. $\quad$ Silvicultural requirements for regeneration of Vitellaria paradoxa (C. F. Gaertn) Hepper. Ibadan, Nigeria: University of Ibadan, 2010. (Ph.D. Thesis).}

Ayeni, M. J.; Ademiluyi, B. O.; Shittu, R. A. Effects of organic and inorganic fertilizers on the growth performance of Solanum nigrum L. Journal of Agriculture and Ecology Research International, v. 5, no. 4 p. 1-6, 2016.

Bamigboye, T. O.; Kayode, J. Effect of light intensity on the growth of Dioscoreophyllum cumminsii. International Journal of Biological Papers, v. 1 p. 36-40, 2016.

Bettaieb, I.; Zakhama, N.; Aidi Wannes, W.; Kchouk, M. E.; Marzouk, B. Water deficit effects on Salvia officinalis fatty acids and essential oils composition. Science Horticulturae, v. 120, p. 271-275, 2009.

Bewley, I. D.; Black, M. Seeds physiology of development and germination. 2. ed. New York: Plenum Press 23, 1994.

Bvenura, C.; Afolayan, A. J. Growth and physiological response of Solanum nigrum L. to organic and/or inorganic fertilizers. Journal of Applied Botany and Food Quality, v. 87, p. 168-174, 2014.

Corell, M.; García, M. C.; Cermeño, P. Effect of the deficit watering in the production and 
quality of the essential oil, in the cultivation of Salvia officinalis L. Acta Horticulturae, v. 826, p. 281-28, 2009.

Devkota, N. R.; Hogson, J. Shade tolerance of pasture species in relation to deciduous trees. Oikos, v. 91, p. 193-202, 2000.

Gonçalves, J. F. C.; Barreto, D. C. S.; Santos, U. M.; Fernandes, A. V.; Sampaio, P. D. T. B.; Buckeridge, M. S. Growth, photosynthesis and stress indicators in young rosewood plants (Aniba rosaeodora Ducke) under different light intensities. Brazilian Journal of Plant Physiology, v. 17, no. 3, p. 325-334, 2005. https://doi.org/10.1590/S167704202005000300007

Hangarter, R. P. Gravity, light and plant form. Plant, Cell and Environment, v. 20, p. 796800, 1997.

Hoddinot, K. T.; Hall, L. M. The responses of photosynthesis and translocation rate to changes in the ratio of light. Canadian Jounal of Botany, v. 60, no. 8, p. 1285-1291, 1982.

Kephart, K. D.; Taylor, S. E. Growth of $\mathrm{C}_{3}$ and $\mathrm{C}_{4}$ perennial under grasses reduced irradiance. Crop Science, v. 32, p.10331038, 1992.

Muraoka, H.; Tang, Y.; Koizumi, H.; Washitani, I. Effects of light and soil water availability on leaf photosynthesis and growth of Arisaema heterophyllum, a riparian forest understorey plant. Journal of Plant Research, v. 115, p. 419-427, 2002.

Ochuodho, J. O.; Modi, A. T. Temperature and light requirements for the germination of Cleome gynandra seeds. South African Journal of Plant and Soil, v. 22, no. 1, p. 4954, 2005.

Odukoya, O. A.; Inya-Agha, S. I.; Segun, F. I.; Sofidiya, M. O.; Ilori, O. O. Antioxidant activity of selected Nigerian green leafy vegetables.
American Journal of Food Technology, v. 2, no. 3, p. 169-175, 2007.

Ologundudu, A. F.; Adelusi, A. A.; Adekoya, K. P. Effect of light stress on germination and growth parameters of Corchorus olitorius, Celosia argentea, Amaranthus cruentus, Abelmoschus esculentus and Delonix regia. Notulae Scientia Biologicae, v. 5, no. 4, p. 468-475, 2013.

Paiva, E. A. S.; Isaias, R. M. S., Vale, F. H. A.; Queiroz, C. G. S. The influence of light intensity on anatomical structure and pigment contents of Tradescantia pallida (Rose) Hunt. cv. purpurea boom (Commelinaceae) leaves. Brazilian Archives of Biology and Technology, v. 46, p. 617624, 2003. https://doi.org/10.1590/S151689132003000400017

Saxena, M. C.; Singh Y. A note on leaf area estimation of intact maize leaves. Indian Journal of Agronomy, v. 10, p. 437-439, 1965.

Sowunmi, L. I.; Afolayan, A. J. Effects of environmental factors and sowing depth on seed germination in Cleome gynandra $\mathrm{L}$. (Capparaceae). Pakistan Journal of Botany, v. 47, no. 6, p. 2189-2193, 2015.

Sysoeva, M. I., Markovskaya, E. F.; Shibaeva, T. G. Plants under continuous light: A review. Plant Stress, v. 4, no. 1, p. 5-17, 2010.

Zervoudakis, G.; Salahas, G.; Kaspiris, G.; Konstantopoulou, E. Influence of light intensity on growth and physiological characteristics of common sage (Salvia officinalis L.). Brazilian Archives of Biology and Technology, v. 55, no. 1, p. 89-95, 2012.

Zhang, S.; Ma, K.; Chen, L. Response of photosynthetic plasticity of Paeonia suffruticosa to changed light environments. Environmental and Experimental Botany, v. 49, p. 121-133, 2003. 